\title{
Potencjał użytkowo-eksploatacyjny butanolu jako paliwa alternatywnego do zasilania silników ZI
}

\section{Utility-exploitation potential of butanol as an alternative fuel designed for car SI engines}

\author{
Zbigniew Stępień \\ Instytut Nafty i Gazu - Państwowy Instytut Badawczy
}

STRESZCZENIE: Coraz bardziej surowe przepisy w zakresie ograniczania szkodliwych składników spalin emitowanych przez silniki spalinowe wymuszają konieczność stosowania na coraz szerszą skalę paliw alternatywnych. Biorąc pod uwagę te wymagania, alkohole stanowią atrakcyjną alternatywę jako komercyjnie wykorzystywane paliwa, w tym zarówno jako paliwa samoistne, jak i w mieszankach z benzyną lub olejem napędowym. Stosowanie paliw alkoholowych może być jednym z istotnych czynników przyczyniających się do ograniczenia emisji szkodliwych składników spalin do atmosfery - pod warunkiem dobrej znajomości właściwości paliw i ich optymalnego wykorzystania. Etanol i butanol są alkoholami uważanymi za najbardziej perspektywiczne biokomponenty do obecnie stosowanych paliw konwencjonalnych. Odznaczają się one korzystnymi właściwościami użytkowo-eksploatacyjnymi i proekologicznymi, pozwalającymi zmniejszyć udział paliw węglowodorowych do zasilania silników, jak i ograniczyć emisję składników szkodliwych do atmosfery, w tym $\mathrm{CO}_{2}$. Dotychczas zdecydowanie większe zastosowanie znalazł etanol, mieszany w różnych proporcjach z benzyną i w wielu krajach powszechnie stosowany do zasilania silników ZI. Wynika to prawdopodobnie ze znacznie większej liczby prac badawczych o znaczeniu poznawczym oraz utylitarnym, które pozwoliły na wcześniejsze i szersze wykorzystanie etanolu jako samodzielnego paliwa lub domieszki do paliwa. Jednak w mieszaninach z benzyną, stosowanych jako paliwa do silników ZI, butanol wykazuje kilka istotnych zalet w porównaniu z etanolem. Butanol jest znacznie mniej higroskopijny, lepiej mieszalny z benzyną i ma większą wartość opałową, co przekłada się na mniejsze zużycie paliwa. Gdy butanol jest mieszany z benzyną, jego blendingowa prężność par jest mniejsza niż w przypadku etanolu, co ułatwia spełnienie wymagań normy EN 228. Największe wady butanolu w stosunku do etanolu w zastosowaniu do paliw stanowiących mieszanki z benzyną to mniejsza wartość liczby oktanowej i mniejsze ciepło parowania oraz większa gęstość i lepkość, co może przyczyniać się do większej względem etanolu skłonności do tworzenia szkodliwych osadów, zarówno w obszarze układu wtrysku paliwa, jak i silnika. W sumie butanol ma większy potencjał w porównaniu do etanolu w zakresie właściwości użytkowo-eksploatacyjnych w zastosowaniu do mieszanek paliw benzynowo-alkoholowych do silników ZI.

Słowa kluczowe: paliwa alkoholowe, etanol, butanol, potencjał użytkowo-eksploatacyjny butanolu, silniki z ZI.

\begin{abstract}
Increasingly stricter rules apply to the protection of the environment, including reduction of emissions of noxious car engine exhaust fumes, enforce necessary the use of alternative fuels on an increasingly wider scale. Taking into account these requirements alcohols constitute an attractive alternative as a commercially used fuels including both as selfcontained fuels as well as in blends with petrol or diesel oil. Application of the alcohol fuels may be an important factor that will help to cut emissions from the transport sector, provided good knowledge of fuel performances and optimal use of them. Ethanol and butanol are the alcohols which are considered to be the most promising biocomponents to the currently used conventional fuels. They have many varied and positive exploitation properties as well as pro-ecological which allow to reduce share of hydrocarbon fuels to power IC engines and reduce harmful emissions as well greenhouse gases into the atmosphere. So far, ethanol was applied more widespread, mixed with petrol in variable proportions and in many countries used to power the SI engines. This is probably due to the substantially more quantities of research of cognitive and utilitarian meaning which allowed earlier and wider utilization of the ethanol as a selfcontained fuel or blending component. However in blends with petrol, used as a fuels for SI engines, butanol shows a few significant advantages in comparison with ethanol. Butanol is significantly less hygroscopic, better miscible with petrol and characterised with higher calorific value which contributes to lower fuel consumption. Once the butanol is mixed with petrol its blending vapour pressure is lower than that of the ethanol making easier conformity with the standard EN 228 . The most significant disadvantageous of the butanol in comparison with ethanol in application to fuels designed as a petrol blends is lower octane number and lower heat of vaporization as well as higher density and viscosity which, in turn, may lead to higher against ethanol tendencies to create harmful deposits both in the area of engine as well as in the fuel injection system. In brief butanol has greater potential against ethanol as regards the performance characteristics in the case of petrol-alcohol blends designed for SI car engines.
\end{abstract}

Key words: alcoholic fuels, ethanol, butanol, utility-exploitation potential of butanol, SI engines.

Autor do korespondencji: Z. Stępień, e-mail: zbigniew.stepien@inig.pl

Artykuł nadesłano do Redakcji: 14.11.2019 r. Zatwierdzono do druku: 16.01.2020 r. 


\section{Wstęp}

Globalna polityka redukcji zanieczyszczeń z sektora transportu drogowego dotyczy emisji szkodliwych składników spalin, takich jak: tlenki azotu $\mathrm{NO}_{\mathrm{x}}$, tlenek węgla $\mathrm{CO}$, niespalone węglowodory HC, cząstki stałe PM, oraz emisji ditlenku węgla $\mathrm{CO}_{2}$, jako składnika gazów cieplarnianych $(\mathrm{GHG}$ - greenhouse gas). Harmonogram ograniczania emisji szkodliwych składników spalin w zakresie $\mathrm{NO}_{\mathrm{x}}, \mathrm{CO}, \mathrm{HC}, \mathrm{PM}$ podają normy emisji „Euro”. Harmonogram zmniejszenia emisji $\mathrm{CO}_{2}$ podano w Rozporządzeniu Parlamentu Europejskiego i Rady (WE) nr 443/2009 z dnia 23 kwietnia 2009 r. określającym normy emisji dla nowych samochodów osobowych w ramach zintegrowanego podejścia Wspólnoty na rzecz zmniejszenia emisji $\mathrm{CO}_{2}$ z lekkich pojazdów dostawczych.

Obecnie coraz bardziej surowe przepisy w zakresie ograniczania szkodliwych składników spalin emitowanych przez silniki spalinowe wraz z nieustannie i nieprzewidywalnie zmieniającymi się cenami paliw wymuszają, między innymi, konieczność stosowania na coraz szerszą skalę paliw alternatywnych. Ma to na celu poprawę właściwości użytkowo-eksploatacyjnych silników, w tym w szczególności zmniejszenia ilości emitowanych do otoczenia zanieczyszczeń i wielkości zużycia paliwa. Kryteria definiujące alternatywne paliwa, które mogą znaleźć zastosowanie do zasilania silników samochodowych, to przede wszystkim ich pochodzenie z odnawialnych, szeroko dostępnych źródeł, niższe koszty produkcji oraz zdolność do łatwego mieszania się z obecnie stosowanymi paliwami z surowców kopalnych i wykorzystania takich mieszanek do zasilania silników bez konieczności ich modyfikacji. Biorąc pod uwagę te wymagania, alkohole stanowią atrakcyjną alternatywę jako komercyjnie wykorzystywane paliwa, w tym zarówno jako paliwa samoistne, jak i w mieszankach $\mathrm{z}$ benzyną lub olejem napędowym. Sprzyja temu w szczególności charakterystyka właściwości użytkowych paliw, zbieżna z wcześniej wskazanymi wymaganiami i oczekiwaniami. Obecnie w Brazylii, Chinach, USA i kilku innych krajach paliwa alkoholowe są szeroko stosowane zarówno jako samodzielne, jak i stanowiące domieszki do paliw konwencjonalnych (Jin et al., 2011). Dotychczas przeprowadzono wiele prac badawczych dotyczących współdziałania paliw konwencjonalnych z różnymi alkoholami
Tabela 1. Wybrane właściwości benzyny i alkoholi (Balki et al., 2014; Sarathy et al., 2014)

Table 1. Selected properties of petrol and alcohols (Balki et al., 2014; Sarathy et al., 2014)

\begin{tabular}{|l|c|c|c|c|c|}
\hline \multicolumn{1}{|c|}{ Wlaściwości } & Benzyna & Metanol & Etanol & Propanol & Butanol \\
\hline \hline Formuła chemiczna & $\mathrm{C}_{8} \mathrm{H}_{18}$ & $\mathrm{CH}_{3} \mathrm{OH}$ & $\mathrm{C}_{2} \mathrm{H}_{5} \mathrm{OH}$ & $\mathrm{C}_{3} \mathrm{H}_{7} \mathrm{OH}$ & $\mathrm{C}_{4} \mathrm{H}_{9} \mathrm{OH}$ \\
\hline Masa cząsteczkowa [Da] & 114 & 32,04 & 46,06 & 60,09 & 74,11 \\
\hline Gęstość $\left[\mathrm{kg} / \mathrm{m}^{3}\right]$ & 736,8 & 792,0 & 794,3 & 789,4 & 806 \\
\hline Wartość opałowa [MJ/kg] & 43,919 & 20,10 & 27,00 & 32,95 & 35,69 \\
\hline Wsp. nadmiaru powietrza & 14,7 & 6,40 & 9,00 & 10,33 & 11,17 \\
\hline Zawartość tlenu [\% $(\mathrm{m} / \mathrm{m})]$ & 0 & 49,90 & 34,70 & 26,60 & 21,60 \\
\hline Ciepło parowania [kJ/kg] & 349 & 1178 & 923 & 761 & 683 \\
\hline Ciśnienie par wg Reida w 37,8 $8^{\circ} \mathrm{C}[\mathrm{kPa}]$ & 63,9 & 31,72 & 19,1 & 13,8 & 6,6 \\
\hline LOB & 95 & 108,7 & 107,4 & 112,5 & 105,1 \\
\hline
\end{tabular}

w zakresie ocen parametrów użytkowych zasilanych nimi silników. Jednak w dalszym ciągu nie w pełni wyjaśniono, w jaki sposób określone właściwości różnych alkoholi wpływają na parametry i właściwości użytkowo-eksploatacyjne silników, w tym wielkość i rodzaj składników szkodliwych emitowanych do atmosfery. Szeroka wiedza dotycząca charakterystyki paliw alkoholowych jest niezbędna do zrozumienia przebiegu procesów spalania w silnikach. Znajomość właściwości paliw jest też konieczna, aby pomóc użytkownikowi w wyborze i stosowaniu paliwa odpowiedniego do określonej konstrukcji silnika i sposobu jego eksploatacji (Surisetty et al., 2011; Masum et al., 2015). Stosowanie paliw alkoholowych może być jednym z istotnych czynników przyczyniających się do ograniczenia emisji szkodliwych składników spalin do atmosfery - pod warunkiem dobrej znajomości właściwości paliw i ich optymalnego wykorzystania.

\section{Właściwości wybranych paliw alkoholowych w zastosowaniu do zasilania silników ZI}

Właściwości paliw, w tym alkoholowych, w odniesieniu do zasilania silników, są związane z ich właściwościami fizykochemicznymi, takimi jak: gęstość, temperatura zapłonu, wartość opałowa, lepkość, prężność par, chemiczna formuła paliwa itp. (Houghton-Alico, 1982). Każdy z wyżej wymienionych parametrów może mieć korzystne bądź niekorzystne oddziaływanie na właściwości użytkowo-eksploatacyjne silnika, w tym szkodliwe emisje do atmosfery. Żeby kompozycja paliwa, a co za tym idzie jego właściwości były zgodne z wymaganiami silników, paliwo (w tym alkoholowe) musi spełniać odpowiednie światowe standardy (EN, DIN, ASTM itd.). W tabeli 1 zawarto wybrane właściwości benzyny i kilku alkoholi.

Liczba oktanowa (LO) określa odporność na niekontrolowany samozapłon paliwa silnikowego do silników ZI, który może powodować jego spalanie stukowe. 
Domieszka alkoholu w benzynie powoduje wzrost liczby oktanowej takiego paliwa względem samej benzyny, co zwiększa odporność na spalanie stukowe i pozwala na zwiększenie kąta wyprzedzenia zapłonu. Skutkuje to wyższym ciśnieniem spalania ładunku w komorze spalania silnika, z czego wynika większa wartość momentu obrotowego silnika. Ponadto większa wartość liczby oktanowej pozwala na poprawną pracę silnika przy większym stopniu sprężania, bez występowania zjawiska spalania stukowego. Badania, które wykonali Eyidogan et al. (2010), wykazały, że metanol zawiera większy udział tlenu niż etanol, a więcej tlenu prowadzi do większej efektywności procesu spalania i w konsekwencji zmniejsza jednostkowe zużycie paliwa. Ponadto zwiększanie zawartości tlenu w paliwie prowadzi do zwiększania liczby oktanowej.

Odporność paliwa na spalanie stukowe ulega znacznemu zmniejszeniu ze wzrostem liczby atomów węgla w alkoholu, przy czym struktury typu ,iso" wykazują większą odporność na spalanie stukowe w porównaniu ze strukturami typu „n”. Stechiometryczny współczynnik nadmiaru powietrza w przypadku alkoholi jest także zależny od liczby atomów węgla zawartych w strukturze alkoholu (Wallner et al., 2013).

Użytkowa energia cieplna zawarta w paliwach jest wyrażana albo w odniesieniu do jednostki masy paliwa, i wówczas nazywana jest wagową wartością opałową [ $\mathrm{kJ} / \mathrm{kg}]$, albo w odniesieniu do objętości paliwa, wtedy jest to objętościowa wartość kaloryczna lub wartość opałowa $\left[\mathrm{kJ} / \mathrm{dm}^{3}\right]$. Zgodnie z normą ASTM D240-17 całkowita energia cieplna (wartość opałowa paliwa) jest definiowana jako ilość ciepła wytworzonego podczas całkowitego spalenia paliwa, mierzona w warunkach stałej objętości lub stałego ciśnienia do momentu, gdy wytworzone gazy (spaliny, para wodna) osiągną temperaturę początkową, w której rozpoczęto proces spalania (wychłodzą się). Wartość opałową dzieli się na górną wartość opałową (HHV, ciepło spalania) i dolną wartość opałową (LHV). Zatem ciepło spalania (HHV) oznacza ilość ciepła, które wydzieli się podczas procesu spalania. Podawana wartość parametru uwzględnia ciepło kondensacji pary wodnej i spalin, a więc produktu spalania, który z założenia nie będzie uwalniany do otoczenia. Wyznaczenie ciepła spalania następuje w warunkach idealnych, a więc zakłada spalanie całkowite i zupełne. Wartość opałowa LHV oznacza ilość ciepła, które wydziela się podczas całkowitego spalania, bez uwzględnienia ciepła, jakie można uzyskać z kondensacji pary wodnej, jak i spalin. Oznacza to, że spalona zostanie cała porcja paliwa (ładunek), a w spalinach nie pojawią się substancje palne. W paliwach alkoholowych wartość opałowa zwiększa się ze wzrostem liczby atomów węgla w alkoholu. Zwiększanie zawartego w alkoholu węgla i wodoru wiąże się ze wzrostem masy cząsteczkowej alkoholu i koreluje ze zmniejszaniem się zawartości tlenu. W rezultacie np. metanol, zawierający jeden atom węgla, i etanol, zawierający dwa atomy węgla, mają mniejszą wartość opałową niż benzyna. Skutkiem tego silnik zasilany tymi alkoholami będzie zużywał więcej paliwa niż w przypadku zasilania benzyną przy rozwijaniu tej samej mocy (Agarwal et al., 2014; Balki et al., 2014). Mając to na uwadze, dążąc do poprawy ekonomiczności pracy silnika, jako jedno z rozwiązań można stosować alkohole zawierające w swym składzie więcej atomów węgla, jak np. butanol $\left(\mathrm{C}_{4} \mathrm{H}_{9} \mathrm{OH}\right)$, mające większą wartość opałową, bardziej zbliżoną do tej, jaką ma benzyna (Elfasakhany, 2014; Masum et al., 2014).

Ciepło parowania - alkohole mają wyższe, względem benzyny, ciepło parowania, co powoduje zmniejszenie temperatury ładunku dostarczanego do cylindrów silnika i wzrost sprawności ich napełniania, a zatem i wzrost mocy silnika. Ponadto paliwa alkoholowe łatwiej odparowują podczas suwu sprężania ładunku mieszanki paliwowo-powietrznej w cylindrach silnika ze względu na większą wartość ciepła parowania. Dzieje się tak dlatego, ponieważ paliwo podczas procesu odparowania, absorbując ciepło z cylindra, sprawia, że mieszanka paliwowo-powietrzna jest łatwiej sprężana, co poprawia sprawność cieplną mieszanki zawierającej alkohol względem benzyny. Równocześnie większe ciepło parowania mieszanek paliw zawierających alkohol ma negatywny wpływ zwłaszcza na zdolności rozruchowe zimnego silnika.

Gęstość paliwa jest ważną właściwością zwłaszcza w przypadku właściwości użytkowo-eksploatacyjnych benzyny silnikowej. Dla przykładu, gęstość paliwa będzie miała wpływ na moc silnika ze względu na wielkość masy paliwa, jakie zostanie dostarczone przez układ wtrysku paliwa do cylindrów silnika (odmierzoną w określonym czasie) (Alptekin i Canakci, 2008).

Lotność paliwa - określa, między innymi, jak szybko paliwo odparowuje, a zatem jak szybko przyczynia się do tworzenia warstwy ozonu, która oddziałuje na otaczające środowisko. Lotność paliwa jest opisywana przez jedną z kilku charakterystyk (właściwości) paliwa, takich jak krzywa destylacji, entalpia odparowania i prężność par. Charakterystyka odparowania paliw alkoholowych stanowi krytyczny parametr z punktu widzenia rozruchu silnika w obniżonej temperaturze, jak również podczas pracy w pełni rozgrzanego silnika. Same alkohole są pojedynczymi związkami chemicznymi i ich właściwości w zakresie parowania opisuje punkt wrzenia, a nie krzywa parowania typowa dla paliw węglowodorowych składających się z wielu związków chemicznych. Przeprowadzone badania dowodzą, że wraz ze wzrostem długości łańcucha węglowego alkoholu zwiększa się temperatura wrzenia alkoholu (Hönig et al., 2014). Fakt, że alkohol odparowuje w określonej temperaturze wrzenia, w przeciwieństwie do określonego zakresu temperatury charakterystycznej dla destylacji np. benzyny, powoduje, że w przypadku mieszanki alkoholu 
z benzyną następuje wydłużenie krzywej zakresu destylacji w punkcie wrzenia alkoholu zawartego w paliwie. Dlatego też temperatura wrzenia alkoholu zawartego $\mathrm{w}$ mieszance $\mathrm{z}$ benzyną w znaczący sposób wpływa na krzywą destylacji paliwa. Generalnie paliwa alkoholowe mają mniejszą prężność par aniżeli benzyna. Lotność paliw alkoholowych zmniejsza się ze wzrostem liczby atomów węgla. Etanol z dwoma atomami węgla ma $\mathrm{w}$ porównaniu $\mathrm{z}$ innymi alkoholami największą prężność par przy $20 \%$ stężenia alkoholu w paliwie (Masum et al., 2015). Oznacza to, że alkohol z większą liczbą atomów węgla będzie wykazywał mniejszą tendencję do tworzenia korków parowych. Należy pamiętać, że mieszanki alkoholi z benzyną, zwłaszcza alkoholi o krótszych łańcuchach, jak metanol czy też etanol, będą wykazywały ograniczenia w temperaturach destylacji i nie będą zachowywały się tak jak idealne mieszanki ze względu na tworzenie mieszanek bliskich azeotropowych. Dlatego też paliwa muszą być odpowiednio lotne dla zagwarantowania łatwego rozruchu silnika i dostatecznie odparowywać dla wymaganego równomiernego rozdziału mieszanki pomiędzy cylindrami.

Lepkość paliwa jest kolejną istotną właściwością, ponieważ ma wpływ na jego zachowanie się podczas wtrysku. Dokładna ilość wtryskiwanego paliwa, dostosowywana do warunków pracy silnika, ma znaczący wpływ na wielkość zużycia paliwa, wielkość emisji składników szkodliwych itp. Generalnie większa lepkość paliwa może prowadzić do gorszego rozpylania (rozdrobnienia) paliwa, a co za tym idzie - utrudnionego jego odparowania i zaburzeń w procesie spalania. Może też powodować zmniejszenie kąta rozpylanej strugi paliwa i zwiększenie jej zasięgu, aż do osiągnięcia ścianek tulei cylindrowych, powodując zmywanie ze ścianek filmu olejowego i rozcieńczanie oleju smarowego w misce olejowej. Wysoka lepkość kinematyczna paliwa i niedostateczne rozdrobnienie rozpylanego paliwa mogą też przyspieszać tworzenie się osadów na elementach silnika i przyspieszać zużycie elementów układu wtrysku paliwa (Utlu i Kocak, 2008; Munoz et al., 2011). Lepkość alkoholi zwiększa się wraz ze wzrostem długości ich łańcuchów węglowych. Znaczy to, że w miarę wzrostu masy cząsteczkowej alkoholu zwiększa się jego lepkość. Dlatego też, zastępując w mieszance metanol (zawierający jeden atom węgla) lub etanol (zawierający dwa atomy węgla) butanolem (zawierającym cztery atomy węgla), otrzymujemy mieszankę o większej lepkości.

Zawartość tlenu w paliwie - obecność tlenu w paliwie poprawia proces spalania paliwa, co przekłada się na poprawę osiągów silnika i zmniejszenie emisji, w szczególności $\mathrm{CO}$ i $\mathrm{HC}$, przy równoczesnym zwiększeniu emisji $\mathrm{CO}_{2} \mathrm{i}-$ na skutek podwyższonej temperatury przy całkowitym spalaniu podwyższonej emisji NO. Wzrost zawartości tlenu w paliwie powoduje zwiększanie jego liczby oktanowej, co pozwala na wzrost stopnia sprężania i poprawę sprawności cieplnej silnika. W przypadku dużej zawartości węglowodorów aromatycznych w paliwie, takich jak toluen, benzen i olefiny, tworzy się duża ilość węglowodorów reaktywnych (Dasilva et al., 2005). $\mathrm{Z}$ tego powodu domieszanie do paliwa związków tlenowych takich jak alkohole redukuje ilość związków aromatycznych. Generalnie zawartość tlenu w alkoholu zmniejsza się w miarę wydłużania łańcucha węglowego. Dla przykładu, butanol jest alkoholem zawierającym cztery atomy węgla, a zatem dwa razy więcej niż zawiera etanol, i równocześnie zawiera $25 \%$ tlenu mniej niż jest w etanolu (Jin et al., 2011). Tlen zawarty w alkoholach tworzących mieszanki z benzyną sprawia, że spalanie takiego paliwa przebiega w sposób bardziej homogeniczny, a zatem pełniejszy, co w szczególności przyczynia się do ograniczenia emisji CO oraz HC. Z kolei zawartość węgla w paliwie lub innej substancji palnej bezpośrednio wiąże się z jego wartością opałową, przy czym im większa liczba atomów węgla w substancji stanowiącej paliwo, tym wyższa jej wartość kaloryczna (opałowa). Tak jest np. w przypadku alkoholi, w których im większa liczba atomów węgla, tym większa zawartość energii w jednostce masy lub objętości, co ma wpływ na poprawę ekonomiczności spalania.

Temperatura zapłonu stanowi parametr paliwa, który wskazuje na wielkość zagrożenia, jakie ono stwarza np. podczas transportu, posługiwania się nim oraz magazynowania. Dla przykładu, butanol jest paliwem dużo bezpieczniejszym w użytkowaniu w podwyższonej temperaturze w porównaniu z innymi alkoholami, ponieważ charakteryzuje się on wysoką temperaturą zapłonu i mniejszą prężnością par (Wallner et al., 2013).

Emisja CO - CO jest produktem niecałkowitego spalania paliwa. CO powstaje na skutek niedoboru tlenu w komorze spalania i dowodzi niepełnego procesu spalania, prowadzącego do spadku mocy silnika. Emisja CO jest wynikiem stosowanych w silnikach technologii, które nie dają możliwości dostarczenia wymaganej, optymalnej ilości powietrza i jego odpowiedniego wymieszania $\mathrm{z}$ rozpylonym paliwem w komorze spalania, co uniemożliwia całkowite spalenie paliwa. Ponadto emisja CO często zwiększa się wraz z wielkością obciążenia silnika, co jest spowodowane zbyt krótkim czasem przebiegu reakcji dla zwiększonej ilości dostarczanego paliwa. Zmniejszenie emisji CO można osiągnąć np. poprzez dodanie do benzyny alkoholu (metanolu, etanolu lub butanolu) przede wszystkim dzięki zawartemu w nich tlenowi, który zostaje wniesiony do spalanego paliwa (Wallner et al., 2013).

Emisja HC - podobnie jak CO, także i HC jest produktem niecałkowitego spalania paliwa w komorach silnika. Formowanie się HC stanowi wynik braku dostatecznej ilości tlenu i niewystarczającego wymieszania paliwa z powietrzem w komorze spalania, niezbędnego do całkowitego spalenia paliwa. 
Wytworzenie i emisja HC wpływa na zmniejszenie mocy silnika, a także zmniejszenie sprawności cieplnej silnika, a zatem na wzrost zużycia paliwa. Podobnie jak w przypadku emisji CO - dodanie do benzyny alkoholu (np. metanolu) znacząco zmniejsza ilość emitowanych HC. W tym przypadku wraz z rosnącym obciążeniem silnika wielkość emisji HC zmniejsza się na skutek wzrostu średniego ciśnienia użytecznego i temperatury ładunku, powodujących szybsze i pełniejsze spalenie paliwa, które dodatkowo jest poprawiane przez związki tlenowe z alkoholi (Wallner et al., 2013).

Emisja $\mathrm{CO}_{2}-\mathrm{CO}_{2}$, w przeciwieństwie do $\mathrm{CO}$ i $\mathrm{HC}$, jest produktem całkowitego spalenia paliwa powodującego emisję $\mathrm{CO}_{2}$. Podczas spalania $\mathrm{HC}$ w obecności wystarczającej ilości powietrza generowane jest ciepło i w wyniku reakcji wytwarza się $\mathrm{CO}_{2}$ i woda. Ze wzrostem obciążenia silnika następuje wzrost emisji $\mathrm{CO}_{2}$, a gdy w paliwie zawarty jest alkohol, więcej tlenu dostarczane jest do procesu spalania paliwa i emisja $\mathrm{CO}_{2}$ zwiększa się ze wzrostem ilości tlenu pochodzącego $\mathrm{z}$ alkoholu zawartego $\mathrm{w}$ paliwie.

Emisja NO - formowanie się NO jest procesem endotermicznym, odbierającym ciepło $\mathrm{z}$ otoczenia, a tym samym zmniejszającym temperaturę otoczenia. Proces tworzenia NO pojawia się przy małym współczynniku nadmiaru powietrza w komorze spalania i wysokiej temperaturze płomienia adiabatycznego. Tworzenie NO może być kontrolowane poprzez obniżanie temperatury płomienia. W przypadku wzrostu tlenu zawartego w paliwie (na skutek dodania alkoholu) dochodzi do całkowitego spalania paliwa, czemu towarzyszy wysoka temperatura i duża emisja NO (Wallner et al., 2013).

\section{Butanol jako paliwo do silników ZI}

W zależności od kształtu cząsteczki butanolu można wyróżnić jego cztery izomery, które noszą nazwy: n-butanol, izobutanol, sec-butanol, tert-butanol. Wszystkie izomery opisuje ta sama formuła chemiczna $\mathrm{C}_{4} \mathrm{H}_{9} \mathrm{OH}$. Nazwa „butanol” (lub ,alkohol butylowy”) nie jest jednoznaczna, odnosi się zazwyczaj do n-butanolu (1-butanolu), czyli związku, w którym grupa hydroksylowa przyłączona jest do skrajnego atomu węgla prostego łańcucha czterowęglowego: $\mathrm{CH}_{3} \mathrm{CH}_{2} \mathrm{CH}_{2} \mathrm{CH}_{2} \mathrm{OH}$. Ten sam łańcuch połączony z grupą hydroksylową przez wiązanie $\mathrm{z}$ jednym $\mathrm{z}$ wewnętrznych atomów węgla nosi nazwę sec-butanol (2-butanol) i występuje w postaci dwóch enancjomerów. Izomer o rozgałęzionym szkielecie węglowym z grupą hydroksylową powiązaną z zewnętrznym atomem węgla to izobutanol (2-metylo-1-propanol), natomiast rozgałęziony izomer z grupą hydroksylową powiązaną z wewnętrznym atomem węgla to tert-butanol (t-butanol, 2-metylo-2-propanol) (Haynes, 2014).
Izomery butanolu mają różną temperaturę krzepnięcia i wrzenia. Są słabo rozpuszczalne w wodzie, gorzej niż etanol i lepiej niż cięższe alkohole (o większej liczbie atomów węgla). Wynika to z tego, że alkohole zawierają z jednej strony polarną grupę hydroksylową, zwiększającą rozpuszczalność w wodzie, a z drugiej - hydrofobowy łańcuch alkilowy, który tę rozpuszczalność pogarsza. Metanol, etanol i propanol są dobrze rozpuszczalne w wodzie, gdyż przeważa tam wpływ struktury polarnej, natomiast butanol jest słabo rozpuszczalny, gdyż oba czynniki są w równowadze (Haynes, 2014). W tabeli 2 zawarto porównanie wybranych właściwości izomerów butanolu.

Butanol produkowany jest przede wszystkim z paliw kopalnych. Podobnie jak etanol - może być produkowany także w drodze fermentacji z biomasy roślinnej, zazwyczaj buraków cukrowych, trzciny cukrowej, ziarna kukurydzy, pszenicy, manioku, słomy, łodyg kukurydzy, odpadów drzewnych, ale również dowolnych innych odpadów roślinnych zawierających węglowodany (Haynes, 2014). Różnica w produkcji etanolu i butanolu polega na wykorzystaniu innego rodzaju mikroorganizmów. W produkcji etanolu są to przede wszystkim drożdże - jednokomórkowe grzyby wytwarzające enzymy do rozkładu węglowodanów, a w przypadku butanolu - szczepy bakterii (Pałuchowska, 2015; Pałuchowska i Stępień, 2017). Proces odbywa się z udziałem bakterii Clostridium acetobutylicum i pozwala na uzyskiwanie butanolu o stężeniu do $7 \%$. W ciągu ostatnich kilkudziesięciu lat odkryto także inne bakterie zdolne do wydajnej produkcji butanolu (np. C. beijerinckii, C. aurantibutyricum i C. butylicum) (George et al., 1983). Prowadzone są badania nad uzyskaniem szczepów produkujących butanol w większym stężeniu (ponad 9\%), umożliwiającym samoczynne rozdzielanie się butanolu od fazy wodnej w trakcie fermentacji (Pierrot et al., 1986). Butanol uzyskany na drodze fermentacji biomasy nazywany jest biobutanolem, a ustawa o biopaliwach nie ogranicza jego rozproszonej produkcji.

Rozważana jest także produkcja butanolu z etanolu przez elektrolizę:

$$
4 \mathrm{C}_{2} \mathrm{H}_{5} \mathrm{OH} \rightarrow 2 \mathrm{C}_{4} \mathrm{H}_{9} \mathrm{OH}+2 \mathrm{H}_{2}+\mathrm{O}_{2}
$$

W zastosowaniu do paliw silnikowych butanol ma wiele zalet w porównaniu $\mathrm{z}$ bardziej rozpowszechnionymi alkoholami, jak etanol czy metanol. Ciepło spalania butanolu wynosi około 83\% ciepła spalania benzyny, co jest wielkością znacznie większą w porównaniu do ciepła spalania etanolu (65\%) i metanolu (48\%) (Yang et al., 2006). Butanol ma też większą wartość opałową i jest znacznie mniej higroskopijny niż metanol, etanol i propanol. Te niższe alkohole są w pełni mieszalne z wodą, podczas gdy butanol jest słabo rozpuszczalny w wodzie. W rezultacie butanol oddziałuje mniej korozyjnie niż np. 
Tabela 2. Wybrane właściwości izomerów butanolu (Holmborn, 2015)

Table 2. Selected properties of butanol isomers (Holmborn, 2015)

\begin{tabular}{|c|c|c|c|c|}
\hline Wlaściwości & sec-butanol & tert-butanol & izobutanol & n-butanol \\
\hline Formuła chemiczna & $\mathrm{C}_{4} \mathrm{H}_{9} \mathrm{OH}$ & $\mathrm{C}_{4} \mathrm{H}_{9} \mathrm{OH}$ & $\mathrm{C}_{4} \mathrm{H}_{9} \mathrm{OH}$ & $\mathrm{C}_{4} \mathrm{H}_{9} \mathrm{OH}$ \\
\hline Masa cząsteczkowa $[\mathrm{g} / \mathrm{mol}]$ & 74,1 & 74,1 & 74,1 & 74,1 \\
\hline Węgiel/wodór/tlen [\% $(\mathrm{m} / \mathrm{m})]$ & $64,8 / 13,6 / 21,6$ & $64,8 / 13,6 / 21,6$ & $64,8 / 13,6 / 21,6$ & $64,8 / 13,6 / 21,6$ \\
\hline Gęstość w temperaturze $15^{\circ} \mathrm{C}\left[\mathrm{kg} / \mathrm{dm}^{3}\right]$ & 0,806 & 0,791 & 0,802 & 0,810 \\
\hline Temperatura wrzenia $\left[{ }^{\circ} \mathrm{C}\right]$ & 100 & 83 & 108 & 117 \\
\hline Temperatura topnienia $\left[{ }^{\circ} \mathrm{C}\right]$ & -115 & 25,7 & -108 & -90 \\
\hline Blending LOB & 101 & $104-110$ & 113 & $94-96$ \\
\hline Blending LOM & 91 & $89-98$ & 94 & $78-81$ \\
\hline Prężność par w $37,8^{\circ} \mathrm{C}[\mathrm{kPa}]$ & & 12 & $3,9\left(\mathrm{w} 40^{\circ} \mathrm{C}\right)$ & $2,4\left(\mathrm{w} 40^{\circ} \mathrm{C}\right)$ \\
\hline Wartość opałowa [MJ/kg] & & 33 & 33 & 33 \\
\hline Wartość opałowa [MJ/l] & & 26,1 & 26,5 & 26,7 \\
\hline Ciepło parowania $[\mathrm{kJ} / \mathrm{kg}]$ & 562 & 536,601 & 579,686 & $584,592,706$ \\
\hline Temperatura samozapłonu $\left[{ }^{\circ} \mathrm{C}\right]$ & 380,406 & 478 & 416,430 & 343 \\
\hline Stechiometr. wsp. nadm. pow. & & 11,1 & 11,2 & 11,2 \\
\hline Rozpuszczalność w wodzie w $20^{\circ} \mathrm{C}[\%(\mathrm{~m} / \mathrm{m})]$ & 37 & mieszalny & 8,5 & 7,7 \\
\hline Temperatura zapłonu $\left[{ }^{\circ} \mathrm{C}\right]$ & 31 & 16 & 28 & 34 \\
\hline Lepkość w temperaturze $20^{\circ} \mathrm{C}[\mathrm{mPa} \cdot \mathrm{s}]$ & & & 3,95 & 2,9 \\
\hline Lepkość w temperaturze $20^{\circ} \mathrm{C}\left[\mathrm{mm}^{2} / \mathrm{s}\right]$ & & & 4,9 & 3,6 \\
\hline Lepkość w temperaturze $40^{\circ} \mathrm{C}\left[\mathrm{mm}^{2} / \mathrm{s}\right]$ & & & 2,7 & 2,3 \\
\hline Napięcie powierzchniowe w $20^{\circ} \mathrm{C}[\mathrm{mN} / \mathrm{m}]$ & & 20,7 & 23,0 & 24,7 \\
\hline
\end{tabular}

etanol, może być przesyłany w standardowych rurociągach i jest dużo bezpieczniejszy w użyciu aniżeli niższe alkohole ze względu na jego wyższą temperaturę wrzenia i temperaturę zapłonu. Zatem butanol jest bardziej kompatybilny z systemem paliwowym przystosowanym do benzyny aniżeli etanol. Ma też lepsze właściwości smarne niż alkohole krótkołańcuchowe. Podobnie jak w przypadku etanolu dodanie butanolu do konwencjonalnego węglowodorowego paliwa do silników z ZI powoduje wzrost liczby oktanowej, umożliwiając zwiększenie stopnia sprężania, zmniejszenie wielkości zużycia paliwa węglowodorowego oraz emisji $\mathrm{CO}_{2}$ (Yacoub et al., 1998; Gautam i Martin, 2000a, 2000b). W porównaniu do n-butanolu izobutanol ma inną strukturę, dzięki czemu charakteryzuje się on większą liczbą oktanową. Podobnie jak w przypadku etanolu - przy mieszaniu butanolu z benzyną o różnym składzie węglowodorowym należy pamiętać, że zarówno oktanowość, jak i lotność są parametrami nieaddytywnymi. Zatem w wyniku zmieszania benzyn o różnym składzie węglowodorowym z butanolem dana właściwość powstałej mieszaniny będzie różna niż wynikałoby to z wyliczenia sumy iloczynów udziałów objętościowych poszczególnych frakcji i ich właściwości fizykochemicznych. Wielkości tzw. blendingowych liczb oktanowych izomerów butanolu są niższe niż w przypadku etanolu. Spośród izomerów butanolu najwyższe blendingowe liczby oktanowe są uzyskiwane dla izobutanolu: blendingowa LOB około 114 i LOM 94. W przypadku n-butanolu blendingowa LOM mieści się w granicach 78-81. Czułość paliwa (różnica pomiędzy LOB i LOM) w przypadku benzyny mieści się w granicach 8-10 jednostek, a dla izomerów butanolu jest to wartość powyżej 10. Szczególnie niska blendingowa LOM występuje w przypadku n-butanolu.

Temperatura wrzenia izobutanolu wynosi $108^{\circ} \mathrm{C}$, a n-butanolu: $117^{\circ} \mathrm{C}$ (Holmborn, 2015). Zatem te izomery butanolu stanowią wyżej wrzące komponenty wprowadzane do mieszaniny $\mathrm{z}$ benzyną, aniżeli ma to miejsce w przypadku zastosowania etanolu (Aakko-Saksa et al., 2014).

Zmieszanie butanolu z benzyną powoduje znaczne zwiększenie udziału komponentów w zakresie średniego zakresu destylacji.

W Europie Fuel Quality Directive 2009/30/EC pozwala na domieszkę do $15 \%(V / V)$ butanolu do benzyny. Izobutanol i tert-butanol są podane oddzielnie, inne izomery butanolu są ujęte w grupie ,inne związki tlenowe”, co oznacza inne monoalkohole i etery o temperaturze wrzenia nie wyższej niż podana w normie EN 228. Około $16 \%(\mathrm{~V} / \mathrm{V})$, tj. $17 \%(\mathrm{~m} / \mathrm{m})$, izobutanolu odpowiada zawartości 3,7\% $(\mathrm{m} / \mathrm{m})$ tlenu w benzynie. Mniejsza zawartość tlenu w butanolu $(21,6 \%(\mathrm{~m} / \mathrm{m}))$ w porównaniu z innymi alkoholami sprawia, że stosując się do wymagań 
normy EN 228, można domieszać więcej niż 10\% (V/V) butanolu do benzyny. 10\% $(\mathrm{V} / \mathrm{V})$ zawartego w benzynie butanolu nie spowoduje też wykroczenia takiego paliwa poza granice gęstości, prężności par i stabilności oksydacyjnej określone w EN 228. Istotną zaletą butanolu jest mniejsze, np. w porównaniu do etanolu, ciepło parowania, co ma zasadnicze znaczenie dla łatwiejszego zimnego rozruchu silnika, zwłaszcza w przypadku niskiej temperatury otoczenia. Tak jak w przypadku każdego alkoholu zastosowanego w mieszance $\mathrm{z}$ benzyną, także mieszanka butanolu z benzyną charakteryzuje się niższym współczynnikiem nadmiaru powietrza w porównaniu z samą benzyną. Dlatego też, stosując mieszankę izobutanolu z benzyną, wielkość natężenia przepływu takiego paliwa dostarczanego do tworzenia mieszanki palnej w silniku musi być większa, żeby zapewnić taki sam względny współczynnik nadmiaru powietrza jak w przypadku samej benzyny. W czasie pracy silnika na biegu jałowym i częściowym obciążeniu układ paliwowy dostarcza mieszankę zbliżoną do stechiometrycznej. Ciśnienie paliwa we wtryskiwaczach jest utrzymywane na określonym (zależnym od typu układu wtrysku paliwa) stałym poziomie. Zatem ilość podawanego do silnika paliwa zależy wyłącznie od czasu otwarcia wtryskiwacza. Wymagany czas wtrysku paliwa jest obliczany w zależności od wielkości obciążenia silnika i wielkości otwarcia przepustnicy, natomiast korekta (regulacja) tego czasu wtrysku jest dokonywana na podstawie sygnału uzyskiwanego z sondy $\lambda$ (zawartego w paliwie tlenu). Przy pełnym obciążeniu silnika zasilanego benzyną układ paliwowy dostarcza wstępnie zdefiniowaną ilość paliwa, właściwą do utworzenia mieszanki palnej o względnym współczynniku nadmiaru powietrza charakteryzującym obszar mieszanek bogatych $(\lambda \sim 0,8-0,9)$, niezależnie od sygnału pochodzącego $z$ sondy $\lambda$. W miarę wzrostu zawartości butanolu w paliwie współczynnik nadmiaru powietrza wzrasta, a zatem tworzona mieszanka jest coraz uboższa (Irimescu, 2009).

W przypadku pośredniego, a w szczególności jednopunktowego wtrysku paliwa należy unikać pracy silnika na ubogiej mieszance. Taka mieszanka nie gwarantuje stabilnego przebiegu procesu spalania. Ponadto spalanie ubogiej mieszanki powoduje zwiększenie emisji $\mathrm{NO}_{\mathrm{x}}$, a także zmniejszenie prędkości propagacji frontu płomienia, prowadzące do wzrostu tendencji spalania stukowego. Zmniejsza to osiągi oraz trwałość silnika.

Dotychczas przeprowadzone badania (Bata et al., 1989) na silniku nieprzystosowanym do spalania paliw o zawartości powyżej 10\% ( $V / V)$ biokomponentu wykazały, że w przypadku stosowania mieszanek zawierających od 10\% $(V / V)$ do $100 \%(V / V)$ butanolu niewielki spadek osiągów odnotowano dla mieszanek zawierających do $20 \%(\mathrm{~V} / \mathrm{V})$ butanolu.

W przypadku zasilania silnika mieszanką zawierającą $70 \%(V / V)$ butanolu maksymalna moc silnika zmniejszyła się o 25\%. Przy zasilaniu silnika 100-proc. butanolem silnik pracował bardzo niestabilnie, a jednostka sterująca wykazywała błąd podczas prób większego obciążania silnika. Przyczyny tak dużych spadków mocy można upatrywać w pogłębiającym się zjawisku spalania stukowego, spowodowanego ubożeniem mieszanki w miarę wzrostu zawartości butanolu w paliwie.

W układzie zasilania z pośrednim wtryskiem paliwa odparowanie paliwa następuje już w kolektorze dolotowym i powoduje obniżanie temperatury ładunku, co przyczynia się do poprawy współczynnika napełnienia komór spalania silnika, zwiększenia masy ładunku palnego i wzrostu wydajności silnika. Butanol ma mniejsze ciepło parowania niż etanol, ale większe niż benzyna, co sprawia, że w wyżej opisanym zakresie będzie miał gorsze właściwości od etanolu, ale lepsze niż sama benzyna. Ze względu na większą w stosunku do etanolu i benzyny lepkość oraz gęstość butanol będzie się też gorzej rozdrabniał podczas rozpylania paliwa, co może powodować większą skłonność do tworzenia osadów na wewnętrznych elementach silnika (zawory dolotowe, komory spalania) (Andersen et al., 2010; Jin et al., 2011; Venugopal i Ramesh, 2013; Elfasakhany, 2016a, 2016b; Elfasakhany i Mahrous, 2016).

Do wad butanolu należy zaliczyć wysoką temperaturę wrzenia i małą prężność par, co ma niekorzystny wpływ na zdolności rozruchowe zimnego silnika (Wallner et al., 2010; Merola et al., 2011; Fenkl et al., 2016). Butanol jest też znacznie droższy w produkcji.

\section{Porównanie butanolu z etanolem jako składników paliw do silników ZI}

Etanol i butanol to alkohole, które są uważane za najbardziej perspektywiczne biokomponenty do obecnie stosowanych paliw konwencjonalnych. Odznaczają się one korzystnymi właściwościami użytkowo-eksploatacyjnymi, jak i proekologicznymi, pozwalającymi zmniejszyć udział paliw węglowodorowych do zasilania silników oraz ograniczyć emisję składników szkodliwych do atmosfery, w tym $\mathrm{CO}_{2}$ (Yacoub et al., 1998; Gautam i Martin, 2000a, 2000b). Dotychczas zdecydowanie większe zastosowanie znalazł etanol, mieszany w różnych proporcjach z benzyną i powszechnie wykorzystywany w paliwach w wielu krajach do zasilania silników z ZI. Wynika to prawdopodobnie ze znacznie większej liczby prac badawczych o znaczeniu poznawczym oraz utylitarnym, które pozwoliły na wcześniejsze i szersze wykorzystanie etanolu jako samodzielnego paliwa lub domieszki do paliwa. Nie bez znaczenia jest też mniejszy koszt wytwarzania etanolu niż butanolu. Jednak biorąc pod uwagę liczne zalety butanolu względem etanolu oraz jego właściwości, bardziej zbliżone 
Tabela 3. Porównanie wybranych właściwości benzyny, n-butanolu, izobutanolu i etanolu (Fenkl et al., 2016)

Table 3. Comparison of selected properties of petrol, n-butanol, isobutanol and ethanol (Fenkl et al., 2016)

\begin{tabular}{|l|c|c|c|c|}
\hline \multicolumn{1}{|c|}{ Wlaściwości } & benzyna & n-butanol & izobutanol & etanol \\
\hline \hline Formuła chemiczna & $\begin{array}{c}\text { złożona mieszanina } \\
\text { związków }\end{array}$ & $\mathrm{C}_{4} \mathrm{H}_{9} \mathrm{OH}$ & $\mathrm{C}_{4} \mathrm{H}_{9} \mathrm{OH}$ & $\mathrm{C}_{2} \mathrm{H}_{5} \mathrm{O}$ \\
\hline LOB & 95 & $94-96$ & 113 & 110 \\
\hline Gęstość $\left[\mathrm{kg} / \mathrm{m}^{3}\right]$ & 753 & 810 & 806 & 790 \\
\hline Masowa wartość opałowa $[\mathrm{MJ} / \mathrm{kg}]$ & 42,9 & 33,3 & 33,3 & 26,8 \\
\hline Objętościowa wartość opałowa $\left[\mathrm{MJ} / \mathrm{dm}^{3}\right]$ & 32,3 & 27,0 & 26,8 & 21,2 \\
\hline Utajone ciepło parowania $[\mathrm{kJ} / \mathrm{kg}]$ & $380-500$ & 716 & 579 & 904 \\
\hline Masowy udział „C” $[\%]$ & 86 & 65 & 65 & 52 \\
\hline Masowy udział „H” $[\%]$ & 14 & 13,5 & 13,5 & 13 \\
\hline Masowy udział „O ${ }^{3}[\%]$ & 0 & 21,5 & 21,5 & 35 \\
\hline Lepkość $[\mathrm{mPa} \cdot \mathrm{s}]$ & $0,4-0,8$ & 2,57 & 3,33 & 1,08 \\
\hline Temperatura wrzenia [ $\left.{ }^{\circ} \mathrm{C}\right]$ & 199 & 118 & 108 & 78 \\
\hline Współczynnik nadmiaru powietrza & 14,7 & 11,2 & 11,2 & 9,0 \\
\hline
\end{tabular}

do właściwości benzyny, uważa się, że ma on większy potencjał w zastosowaniu do przyszłościowych paliw proekologicznych. W tabeli 3 zawarto porównanie wybranych właściwości benzyny, n-butanolu, izobutanolu i etanolu.

Zarówno butanol, jak i etanol mają większą gęstość niż benzyna. W krajach europejskich dąży się do utrzymania gęstości benzyn w zakresie dolnej granicy określonej w normie EN 228.

Powodem takiego dążenia jest duży udział samochodów napędzanych silnikami ZS, co prowadzi do rozszerzenia zakresu destylacji oleju napędowego, z czego wynika zwiększenie zakresu gęstości olejów napędowych, a ponadto im niższa gęstość benzyny, tym więcej można do niej domieszać związków tlenowych, zwykle o większej gęstości niż benzyna. Butanol ma większą gęstość niż etanol, zatem jego maksymalny dopuszczalny udział $\mathrm{w}$ mieszankach $\mathrm{z}$ benzyną jest mniejszy aniżeli etanolu, biorąc pod uwagę zawarte w normie EN 228 wymagania co do gęstości benzyny (mieszaniny).

Zarówno w miarę wzrostu zawartości n-butanolu, jak i etanolu w mieszaninie $\mathrm{z}$ benzyną wartość opałowa mieszaniny zmniejsza się w przybliżeniu w sposób liniowy. Jednak na skutek większej wartości opałowej n-butanolu względem etanolu, zarówno w odniesieniu do jednostki masy, jak i objętości, wartość opałowa mieszaniny zawierającej n-butanol zmniejsza się w mniejszym stopniu w miarę wzrostu zawartości n-butanolu w porównaniu $\mathrm{z}$ analogicznym wzrostem etanolu. Dlatego też mieszaniny benzyny zawierające określoną ilość n-butanolu będą powodowały mniejsze zużycie paliwa przez silnik w porównaniu z mieszaninami benzyny o tej samej zawartości etanolu (Castagliola et al., 2013; Elfasakhany, 2016a, 2016b; Galloni et al., 2016; Fourier et al., 2016).

Zwiększanie zawartości etanolu w mieszaninie $\mathrm{z}$ benzyną będzie powodowało wzrost liczby oktanowej takiego paliwa.
Jest to bardzo korzystne ze względu na możliwość stosowania takiego paliwa w silnikach o większym stopniu sprężania, a zatem o większej sprawności, lub możliwość uniknięcia stosowania w takich paliwach dodatków zwiększających liczbę oktanową. W przeciwieństwie do etanolu n-butanol charakteryzuje się liczbą oktanową zbliżoną do benzyny i dlatego zwiększanie jego udziału w mieszaninie z benzyną nie będzie miało wpływu na zmianę wielkości liczby oktanowej. Zatem biorąc pod uwagę ten parametr użytkowo-eksploatacyjny, butanol jest łatwiej wymienny z benzyną niż etanol.

Jeśli chodzi o zmiany wielkości prężności par mieszanin benzyny ze zwiększającym się udziałem n-butanolu to wyraźne zmniejszanie się prężności par mieszanin benzyny z n-butanolem jest obserwowane w przypadku każdej założonej granicy zawartego tlenu i wynika z mniejszej prężności par n-butanolu w porównaniu z zastępowanym w mieszaninach etanolem. Spadek jest tym większy, im mniejsza jest założona zawartość tlenu w mieszaninie.

\section{Podsumowanie}

Rozważając wybór alkoholu mieszanego z benzyną jako paliwa do silnika spalinowego ZI, należy wziąć pod uwagę kilka krytycznych właściwości takiego paliwa z punktu widzenia wymagań silnika. Podczas gdy wartość opałowa zawarta $\mathrm{w}$ jednostce masy paliwa $\mathrm{z}$ alkoholem jako miara energii jest ważna z punktu widzenia walorów energetycznych paliwa, to wartość opałowa odniesiona do objętości paliwa będzie miała znaczący wpływ na czas wtrysku paliwa, a zatem na jakość tworzenia mieszanki paliwowo-powietrznej w czasie, i może mieć wpływ na pracę silnika. Jest to szczególnie 
istotne w typowym obecnie rozwiązaniu układu wtrysku paliwa, tzn. bezpośrednim wtrysku, w którym odpowiednia, zależna od warunków pracy silnika ilość paliwa jest dostarczana do komór spalania poprzez regulację czasu trwania wtrysku.

$\mathrm{W}$ mieszaninach $\mathrm{z}$ benzyną stosowanych jako paliwa do silników ZI butanol wykazuje kilka istotnych zalet w porównaniu $z$ etanolem. Butanol jest znacznie mniej higroskopijny, lepiej mieszalny z benzyną i ma większą wartość opałową, co przekłada się na mniejsze zużycie paliwa (mieszanek zawierających butanol w stosunku do mieszanek zawierających etanol). Gdy butanol jest mieszany z benzyną, jego blendingowa prężność par jest niższa niż w przypadku etanolu, co ułatwia spełnienie wymagań normy EN 228.

Największe wady butanolu w stosunku do etanolu w zastosowaniu do paliw stanowiących mieszanki z benzyną to mniejsza liczba oktanowa i mniejsze ciepło parowania oraz większa gęstość i lepkość, co może przyczyniać się do większej względem etanolu skłonności do tworzenia szkodliwych osadów, zarówno w obszarze układu wtrysku paliwa, jak i silnika (zawory i kanały dolotowe oraz komory spalania). W sumie butanol ma większy potencjał w porównaniu do etanolu w zakresie właściwości użytkowo-eksploatacyjnych w zastosowaniu do mieszanek paliw benzynowo-alkoholowych do silników ZI.

Artykuł powstał na podstawie pracy statutowej pt.: Badania wpływu paliwa zawierajacego $w$ swym składzie 20\% v/v butanolu na tworzenie osadów $w$ silniku $Z I$ - praca INIG - PIB na zlecenie MNiSW; nr zlecenia: 0011/TE/2019, nr archiwalny: DK-4100-0003/2019.

\section{Literatura}

Aakko-Saksa P., Rantanen-Kolehmainen L., Koponen P., Engman A., Kihlman J., 2011. Biogasoline options - Possibilities for achieving high bio-share and compatibility with conventional cars. $S A E$ International Journal of Fuels and Lubricants, 4(2): 298-317.

Agarwal A.K., Karare H., Dhar A., 2014. Combustion, performance, emissions and particulate characterization of a methanol-gasoline blend (gasohol) fuelled medium duty spark ignition transportation engine. Fuel Processing Technology, 12: 16-24

Alptekin E., Canakci M., 2008. Determination of the density and the viscosities of biodiesel-diesel fuel blends. Renewable Energy, 33(12): 2623-2630.

Andersen V.F., Anderson J.E., Wallington T.J., Nielsen O.J., 2010. Vapor pressures of alcohol-gasoline blends. Energy Fuels, 24(16): 3647-3654.

Balki M., Sayin C., Canakci M., 2014. The effect of different alcohol fuels on the performance, emission and combustion characteristics of a gasoline engine. Fuel, 115: 901-906.

Bata R.M., Elrod A.C., Lewandowski T.P., 1989. Butanol as a Blending Agent With Gasoline for IC Engines. SAE, paper 890434

Castagliola M.M., De Simio L., Iannaccone S., Prati M.V., 2013. Combustion efficiency and engine-out emissions of a SI engine fueled with alcohol/gasoline blends. Appl. Energy, 111: $1162-1171$
Dasilva R., Cataluna R., Menezes E., Samios D., Piatnicki C., 2005. Effect of additives on the antiknock properties and Reid vapor pressure of gasoline. Fuel, 84(7-8): 951-959.

Elfasakhany A., 2014. Experimental study on emissions and performance of an internal combustion engine fuelled with gasoline and gasoline/n-butanol blends. Energy Conversion and Management, 88: 277-283.

Elfasakhany A., 2016a. Experimental study of dual n-butanol and iso-butanol additives on spark-ignition engine performance and emissions. Fuel, 163: 166-174.

Elfasakhany A., 2016b. Performance and emissions of spark-ignition engine using ethanol-methanol-gasoline, n-butanol-iso-butanolgasoline and iso-butanol-ethanol-gasoline blends. Eng. Sci. Technol. Int. J., 19: 2053-2059.

Elfasakhany A., Mahrous A-F., 2016. Performance and emissions assessment of n-butanol-methanol-gasoline blends as a fuel in spark-ignition engines. Alexandria Engineering Journal, 55(3): 3015-3024. DOI: 10.1016/j.aej.2016.05.016.

Eyidogan M., Ozsezen A.N., Canakci M., Turkcan A., 2010. Impact of alcohol-gasoline fuel blends on the performance and combustion characteristics of an SI engine. Fuel, 89(10): 2713-2720.

Fenkl M., Pechout M., Vojtisek M., 2016. N-butanol and isobutanol as alternatives to gasoline: Comparison of port fuel injector characteristics. EPJ Web of Conferences, 114: 02021. DOI: 10.1051/ epjconf/201611402021.

Fourier E., Simon G., Seers P., 2016. Evaluation of low concentrations of ethanol, butanol $\mathrm{BE}$, and $\mathrm{ABE}$ with gasoline direct-injection, spark-ignition engine. Fuel, 181: 396-407.

Galloni E., Fontana G., Staccone S., Scala F., 2016. Performance analyses of a spark-ignition engine firing with gasoline-butanol blends at partial load operation. Energy Convers. Manag., 110: 319-326.

Gautam M., Martin D.W., 2000a. Emission characteristics of higheralcohol/gasoline blends. Proc. Inst. Mech. Eng. A - Power Energy, 214: $165-182$.

Gautam M., Martin D.W., 2000b. Combustion characteristics of higher-alcohol/gasoline blends. Proc. Inst. Mech. Eng. A-Power Energy, 214: 497-511.

George H.A., Johnson J.L., Moore W.E., Holdeman L.V. et al., 1983. Acetone, Isopropanol, and Butanol Production by Clostridium beijerinckii (syn. Clostridium butylicum) and Clostridium aurantibutyricum. Appl. Environ. Microbiol., 45(3): 1160-1163.

Haynes W.M., 2014. Handbook of Chemistry and Physics. 95 Edition. CRC Press.

Holmborn J., 2015. Alternative fuels for Internal Combustion Engines. Institutionen for Maskinkonstruktion. Skolan for industriell teknik och management. KTH. Report within project "A pre-study to prepare fpr interdisciplinary research on future alternative transportation fuels", financed by The Swedish Energy Agency.

Hönig V., Kotek M., Marik J., 2014. Use of butanol as a fuel for internal combustion engines. Agronomy Research, 12(2): 333-340.

Houghton-Alico D., 1982. Alcohol fuels: policies, production, and potential. Westview Press.

Irimescu A., 2009. Full Load Performance of a Spark Ignition Engine Fueled with Gasoline-Isobutanol Blends. Analele Universitatii “Eftimie Murgu” Resita, Anul XVI, 1: 151-156. ISSN 1453-7397.

Jin C., Yao M., Liu H., Lee C.F., Ji J., 2011. Progress in the production and application of n-butanol as a biofuel. Renewable and Sustainable Energy Reviews, 15(8): 4080-4106.

Masum B., Masjuki H.H., Kalam M.A., Palash S.M., Habibullah M., 2015. Effect of alcohol-gasoline blends optimization on fuel properties, performance and emissions of a SI engine. Journal of Cleaner Production, 86: 230-237. 
Masum B.M., Masjuki H.H., Kalam M.A., Palash S.M., Wakil M.A., Imtenan S., 2014. Tailoring the key fuel properties using different alcohols (C2-C6) and their evaluation in gasoline engine. Energy Conversion and Management, 88: 382-390.

Merola S., Tornatore C., Valentino G., Marchitto L. et al., 2011. Optical Investigation of the Effect on the Combustion Process of Butanol-Gasoline Blend in a PFI SI Boosted Engine. SAE Technical Paper, 2011-24-0057. DOI: 10.4271/2011-24-0057.

Munoz M., Moreno F., Monne C., Morea J., Terradillos J., 2011. Biodiesel improves lubricity of new low Sulphur diesel fuels. Renewable Energy, 36(11): 2918-2924.

Pałuchowska M., 2015. Butanol produkowany z biomasy. NaftaGaz, 7: 502-509.

Pałuchowska M., Stępień Z., 2017. Oceny paliw etanolowych w testach silnikowych i eksploatacyjnych. Nafta-Gaz, 2: 97-104. DOI: 10.18668/NG.2017.02.04

Pierrot P., Fick M., Engasser J.M., 1986. Continuous acetone-butanol fermentation with high productivity by cell ultrafiltration and recycling. Biotechnol. Lett., 8(4): 253-256.

Sarathy S.M., O $\beta$ wald P., Hansen N., Kohse-Höinghaus K., 2014. Alcohol combustion chemistry. Progress in Energy and Combustion Science, 44: 40-102.

Surisetty V.R., Dalai A.K., Kozinski J., 2011. Alcohol as alternative fuels: An overview. Applied Catalysis A General, 404(1): 1-11.

Utlu Z., Kocak M.S., 2008. The effect of biodiesel fuel obtained from waste frying oil on direct injection diesel engine performance and exhaust emissions. Renewable Energy, 33(8): 1936-1941.

Venugopal T., Ramesh A., 2013. Effective utilization of butanol along with gasoline in a spark ignition engine through a dual injection system. Appl. Thermal Eng., 59: 550-558.
Wallner T., Ickes A., Lawyer K., 2013. Analytical Assessment of $\mathrm{C}_{2}-\mathrm{C}_{8}$ Alcohols as Spark-Ignition Engine Fuels. Proceedings of the FISITA 2012 World Automotive Congress, Lecture Notes in Electrical Engineering, 191. DOI: 10.1007/978-3-642-33777-2_2.

Wallner T., Ickes A., Shidore N., 2010. Impact of ethanol and butanol as oxygenates on SIDI engine efficiency and emissions using steady-state and transient test procedures. $16^{\text {th }}$ Directions in Engine-Efficiency and Emissions Research (DEER) Conference, Detroit, Michigan.

Yacoub Y., Bara R., Gautam N., 1998. The performance and emission characteristics of $\mathrm{C} 1-\mathrm{C} 5$ alcohol-gasoline blends witch matched oxygen content in a single cylinder spark ignition engine. Proc. Inst. Mech. Eng. A - Power Energy, 212: 363-379.

Yang H., Yan R., Chen H., Zheng C., Lee D.H., Liang D.T., 2006. In-depth investigation of biomass pyrolysis based on three major components: hemicellulose, cellulose and lignin. Energy and Fuels, 20: 388-393.

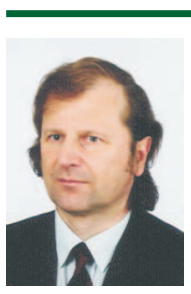

Dr hab. inż. Zbigniew STĘPIEŃ, prof. INiG - PIB Kierownik Zakładu Oceny Właściwości Eksploatacyjnych, kierownik Pracowni Badań Silnikowych i Trybologicznych Zakładu Oceny Właściwości Eksploatacyjnych Instytut Nafty i Gazu - Państwowy Instytut Badawczy ul. Lubicz 25 A, 31-503 Kraków E-mail: zbigniew.stepien@inig.pl

\section{OFERTA BADAWCZA ZAKŁADU OCENY WŁAŚCIWOŚCI EKSPLOATACYJNYCH}

ocena w testach laboratoryjnych właściwości fizykochemicznych oraz użytkowo eksploatacyjnych wg najnowszych procedur badawczych zarówno europejskich jak i amerykańskich:

» paliw ciektych, biopaliw i biokomponentów,

» materiatów smarnych w tym: olejów silnikowych, przekładniowych i przemysłowych zarówno świeżych, jak i przepracowanych;

- $\quad$ petny zakres ustug w zakresie nowoczesnego planowania, monitorowania i oceny zmian właściwości olejów smarowych w eksploatacji, doradztwo i ekspertyzy w zakresie problemów powstałych na skutek użytkowania olejów niewtaściwej jakości lub ich niewtaściwej eksploatacij;

szeroki zakres ocen stanowiskowych właściwości trybologicznych paliw, środków smarowych oraz cieczy hydraulicznych;

oceny liczb oktanowych i cetanowych w testach silnikowych wg procedur europejskich i amerykańskich;

jedyne w kraju oceny wtaściwości użytkowo-eksploatacyjnych paliw silnikowych prowadzone na silnikowych stanowiskach badawczych wg ogólnoeuropejskich procedur opracowanych przez CEC i wymaganych między innymi przez Światową Kartę Paliw;

oceny kompatybilności dodatków do paliw i olejów smarowych, ustugi eksperckie w zakresie problemów związanych z niekompatybilnością wymienionych produktów w eksploatacij;

ustugi eksperckie w zakresie wpływu jakości paliw na możliwości powstania dysfunkcji i uszkodzeń silnikowych układów wtrysku paliwa;

doradztwo w zakresie eksploatacji silnikowych układów oczyszczania spalin wyposażonych w filtry cząstek statych.

Kierownik: dr inż. hab. Zbigniew Stępień, prof. INiG - PIB Adres: ul. Łukasiewicza 1, 31-429 Kraków Telefon: 126177578 Faks: 126177522 E- mail: zbigniew.stepien@inig.pl

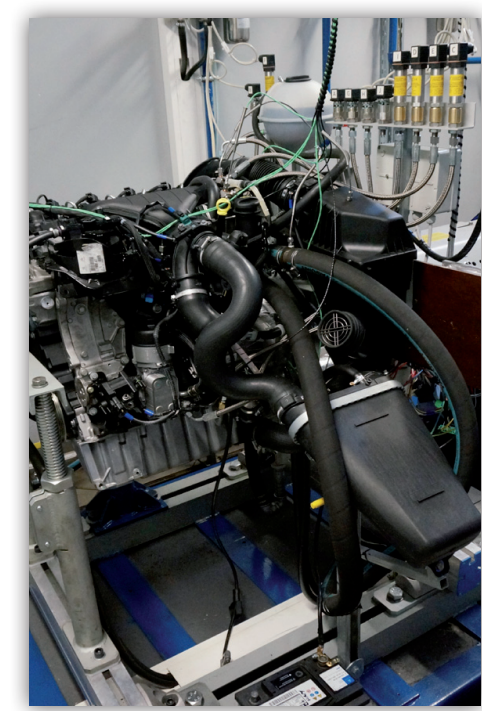

INSTYTUT NAFTY I GAZU

- Państwowy Instytut Badawczy 